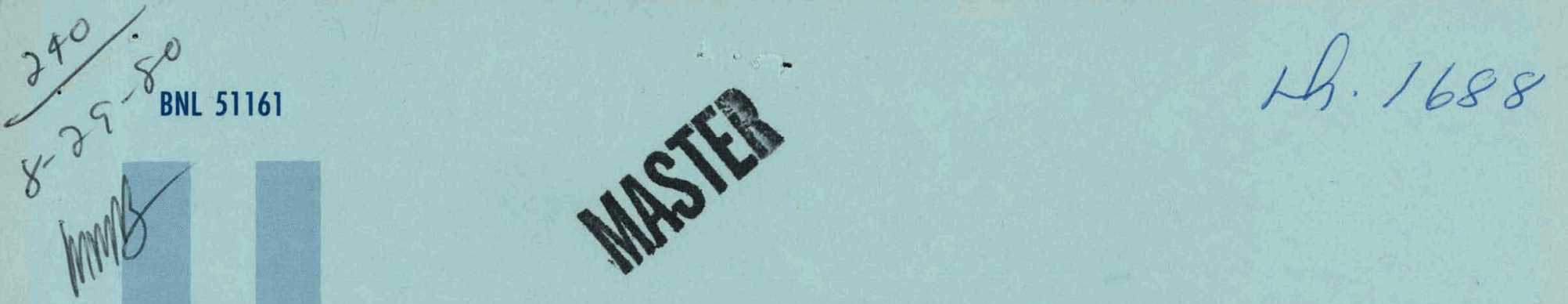

\title{
THE 1979 BREEDING BIRD CENSUSES AND SUMMARY OF 1977-1979 RESULTS
}

\author{
GILBERT S. RAYNOR
}

November 1979

DEPARTMENT OF ENERGY AND ENVIRONMENT

BROOKHAVEN NATIONAL LABORATORY UPTON, NEW YORK 11973 


\section{DISCLAIMER}

This report was prepared as an account of work sponsored by an agency of the United States Government. Neither the United States Government nor any agency Thereof, nor any of their employees, makes any warranty, express or implied, or assumes any legal liability or responsibility for the accuracy, completeness, or usefulness of any information, apparatus, product, or process disclosed, or represents that its use would not infringe privately owned rights. Reference herein to any specific commercial product, process, or service by trade name, trademark, manufacturer, or otherwise does not necessarily constitute or imply its endorsement, recommendation, or favoring by the United States Government or any agency thereof. The views and opinions of authors expressed herein do not necessarily state or reflect those of the United States Government or any agency thereof. 


\section{DISCLAIMER}

Portions of this document may be illegible in electronic image products. Images are produced from the best available original document. 
BNL 51161

UC-11

(Environmental Control Technology and

Earth Sciences - TID-4500)

\title{
THE 1979 BREEDING BIRD CENSUSES AND SUMMARY OF 1977-1979 RESULTS
}

\author{
GILBERT S. RAYNOR
}

November 1979

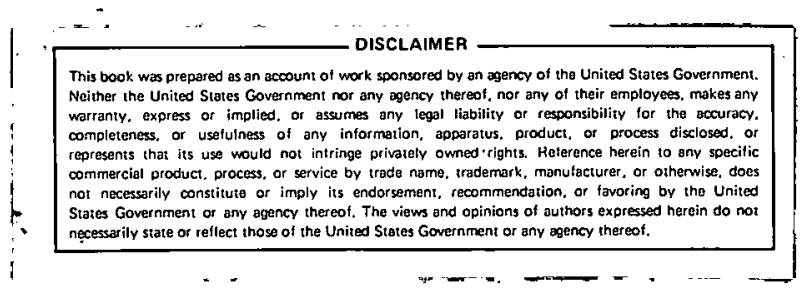

LAND AND FRESHWATER ENVIRONMENTAL SCIENCES GROUP DEPARTMENT OF ENERGY AND ENVIRONMENT

BROOKHAVEN NATIONAL LABORATORY

ASSOCIATED UNIVERSITIES, INC.

UNDER CONTRACT NO. DE-ACO2-76CH00016 WITH THE UNITED STATES DEPARTMENT OF ENERGY 


\section{DISCLAIMER}

This bouk was plepalch as all accuunt of woik sjuinsored by an ageney of the United States Government. Neither the United States Government nor any agency thereor, nor any of their employees, makes any warranty, express or implied, or assumes any legal liability or responsibility for the accuracy, completeness, or usefulness of any information, apparatus, product, or process disclosed, or represents that its use would not Infringe privately owned rights. Reference herein tu any specific cunnuercial pivduct. process. or service by trade name, trademark, manufacturer, or otherwise, does not necessarily constitute or imply its endorsement, recommendation, or favoring by the United States Government or any agency thereof. The views and opinions of authors expressed herein do not necessarily state or reflect those of the United States Government or any agency thereof.

Printcd in the United States of America

$$
\text { Available from }
$$

National Technical Information Service

U.S. Department of Commerce

5285 Port Royal Road

Springfield, VA 22161

Price: Printed Copy $\$ 4.00$; Microfiche $\$ 3.00$ 


\section{ABSTRACT}

As part of a program to characterize the plant and animal life of the Laboratory site and the surrounding region, the two breeding bird censuses originated in 1977 were continued in 1979. Twelve census trips were made to the BNL plot and 10 to the Westhampton plot by seven volunteer observers. Comparisons of data from the three years showed that the number of territorial males on the BNL plot did not change significantly, but the number of breeding species showed a continuous decline, from 18 to 10 . Littie change in the number of territorial males or in species composition occurred in the Westhampton plot. 


\section{INTRODUCTION}

The breeding bird censuses originated in 1977 to aid in characterizing the plant and animal life of the Brookhaven National Laboratory (BNL) site and the surrounding region were continued on the BNL and Westhampton plots in 1979. The plots were described and results of the 1977 and 1978 censuses were reported earlier. ${ }^{1-3}$. The 1979 censuses were conducted by seven volunteer observers working on their own time: Robert Adamo, James Clinton, Edward Kemnitzer, David Larsen, Gilbert Raynor, John Ruscica, and Kathleen Tuohy. Adamo and Kemnitzer are not affiliated with BNL and worked only on the Westhampton plot.

No significant changes occurred in the vegetation of either plot or in the vicinity of the Westhampton plot, although single plants of two species not previously observed were noted on the Westhampton plot. These are Black Cherry (Prunus serotina) and Virginia Juniper (Juniperus virginiana).

Clearing of about 200 acres of woodland for the ISABELLE project a short distance west of the BNL plot occurred prior to the 1979 census period. It was anticipated that birds displaced from former breeding territories by the forest clearing might increase populations in the nearby census plot. Only one species, the Brown Thrasher, showed a significant increase, but a less significant increase occurred in the Westhampton plot also. Thus, this apparent change in population cannot definitely be ascribed to the nearby habitat change but may have resulted from it.

\section{RESULTS AND DISCUSSION}

Prior to the 1979 census period, most of the wooden stakes used as grid markers on the Westhampton plot had to be replaced due to damage by termites and other causes. The lower portions of the replacement stakes were treated to minimize future damage. Numbers were repainted on stakes not replaced. At BNL, a number of broken and missing stakes were replaced. Only a few others needed repainting.

A description of the census trips with weather conditions is given in Table 1. Total coverage was similar to that of preceding years, but the timing of the visits was based on results obtained in 1977 and 1978. Trips were concentrated in late May and June, the height of the breeding season. Man-hours at BNL totaled 28.5 and at Westhampton 27. No evening trips were wade in 1979 to check for nocturnal species.

The species composition and density of territorial males on the BNL plot are given in Table 2 and on the Westhampton plot in Table 3. Reports on these censuses will also be published in American Birds with others from throughout North America.

Now that three years of data have been obtained, meaningful comparisons are possible. The numbers of territorial males on the BNL plot for the three years are listed in Table 4. A species listed by "+" is one having less than a full territory on the plot. A species designated by " $v$ " is a visitor, one that does not hold territory on the plot but probably nests nearby. Although the total number of territorial males on the BNL plot shows no trend, the number of territorial species shows a sharp decline. The most significant loss was of the Black and White Warbler, but seven other species declined from territorial in 1977 to visitor or completely absent in 1979. The reasons for these changes are not evident, and continued monitoring is required. 
Similar information is given in Table' 5 for the Westhampton plot. Here, little change is evident in the number of territorial males. The slight increase in number of breeding species is not considered significant since species changed only from $v$ to + . Thus, the evidence suggests rather stable populations in the dwarf pine plains.

Visitors to the BNL plot not listed in Table 4 included Wood Pewee, Common Crow, Robin, Common Grackle, and Brown-headed Cowbird. Visitors to the Westhampton plot not listed in Table 5 included Red-tailed Hawk, Bobwhite, Mourning Dove, Black-billed Cuckoo, Barn Swallow, Purple Martin, Blue Jay, Black-capped Chickadee, Catbird, Robin, Red-winged Blackbird, and Common Grackle. A greater number of visiting species are detected on the Westhampton plot due to the low vegetation and the clear view in all directions from almost all locations. In the BNL plot, the canopy is largely closed and birds flying overhead can seldom be seen although they are sometimes heard.

\section{DESCRIP'ION OF METHODS}

The observational and analytical methods used in this study were described briefly earlier, 1 but more detail seems desirable to facilitate understanding of the methods and evaluation of the results.

un each census trip, the observer walks slowly along adjacent or alternate grid rows in order to cover the plot in a systematic fashion but deviates from the fixed route when necessary to locate more precisely a bird seen or heard at some distance. Each bird seen or heard on or near the plot is marked on a scale map of the plot using letter symbols for each species and other symbols to indicate song, aggressive interactions between males, movements, and the simultaneous presence of two or more birds of the same species.

As an example, in Figure 1, a map of the BNL plot, all singing males located precisely are indicated by a closed circle around the letter symbol. A11 singing males located only approximately are indicated by a broken circle. Birds engaged in behavior indicative of nesting, e.g., carrying nesting material or food, are indicated by a square. Solid arrows indicate the direction in which birds are observed to move and the approximate distance. Such observations help to define the boundaries of the territorles since territorial males do not normally leave their territory. Dashed double-ended arrows point to two birds of the same species seen or heard simultaneously, clear proof of a territorial boundary between them. Two birds observed in conflict are assumed to be near the common boundary of their respective territories. Their symbols are enclosed by a solid jagged line. Thus, a map similar to Figure 1 is completed for each census trip.

At the end of the census period, a composite map is prepared for each species by transferring all data for that species from all trip maps to the composite map. Figure 2 illustrates the 1979 composite map for the Rufoussided Towhee on the BNL plot. The numbers indicate the tripg on which the observations were made. Other symbols are identical to those on the trip maps.

Territorial boundaries are determined by several criteria: a cluster of at least three observations in one area is assumed to indicate a territory. Aggressive encounters such as that shown between $B$ and $C$ and 5 and 6 on Figure 2 define boundaries. In addition, boundaries must occur between simultaneous observations of two or more conspecific males. Using these criteria, approximate territorial boundaries were drawn as shown on Figure 2. Here, 14 territories were located within or mostly within the plot and several others 
partially within or nearby. Partial territories are added to complete ones to determine the average number of territorial males on the plot. As shown in Table 2, 14 Rufous-sided Towhee territories were estimated from this plut.

Note that the territory size tends to be smaller when territories are closer together as in the northwestern portion of the plot. This presumably indicates a more favorable area and greater competition between adjacent males. In the southern portion of the plot, territories are fewer and larger suggesting less favorable conditions there for this species.

The location of territories as well as their number is subject to change from year to year. As an example, the location of all Ovenbird territories on the BNL plot for the three years is plotted in Figure 3. As shown in Table 4, the number of territories remained nearly constant, from 7 to 8 each year. It may also be significant that the location of territories showed considerable similarity from year to year. This would indicate either site fidelity if the same males returned in succeeding years or more favorable habitat if different males occupied the same territory in different years.

Regardless of the reason, it is obvious that the northwest, north central, south central, and southeast portion of the grid are favored since much of these areas was occupied each year. In contrast, the southwest corner and east central region were not utilized in any year. Detailed studies of the small vegetational differences between the favored and less favored regions would assist in better understanding of the habitat requirements of this species. Similar studies for all species on both plots would be even more valuable but are not presently within the capabilities of the volunteer participants in this project.

\section{FUTURE PLANS}

Birds are among the most sensitive and easily observed indicators of environmental quality. Changes in bird populations usually result from environmental changes either locally or elsewhere within the range of the species. Census data of the type reported here provide the quantitative documentation needed to monitor population changes and causative changes in the environment. Such data become more valuable as the length of record increases. Longer term trends can only be distinguished from shorter period fluctuations by continued measurements. Therefore, the study will be continued as long as feasible. 


\section{REFERENCES}

1. Raynor, G.S., Ruscica, J.J., Clinton, J.H., and Larsen, D.L., The 1977 Breeding Bird Censuses and Vegetation Surveys in Two Successional Stages of Oak-Pine Forest, 24 pp., BNL 50775, 1977.

2. Raynor, G.S., The 1977 Breeding-Bird Census, 4 pp., BNL 50933, 1978.

3. VanVelzen, W.T. (Ed.), Forty-second breeding bird census, Am. Birds 33: 68-69 (censuses 48 and 50) (1979). 


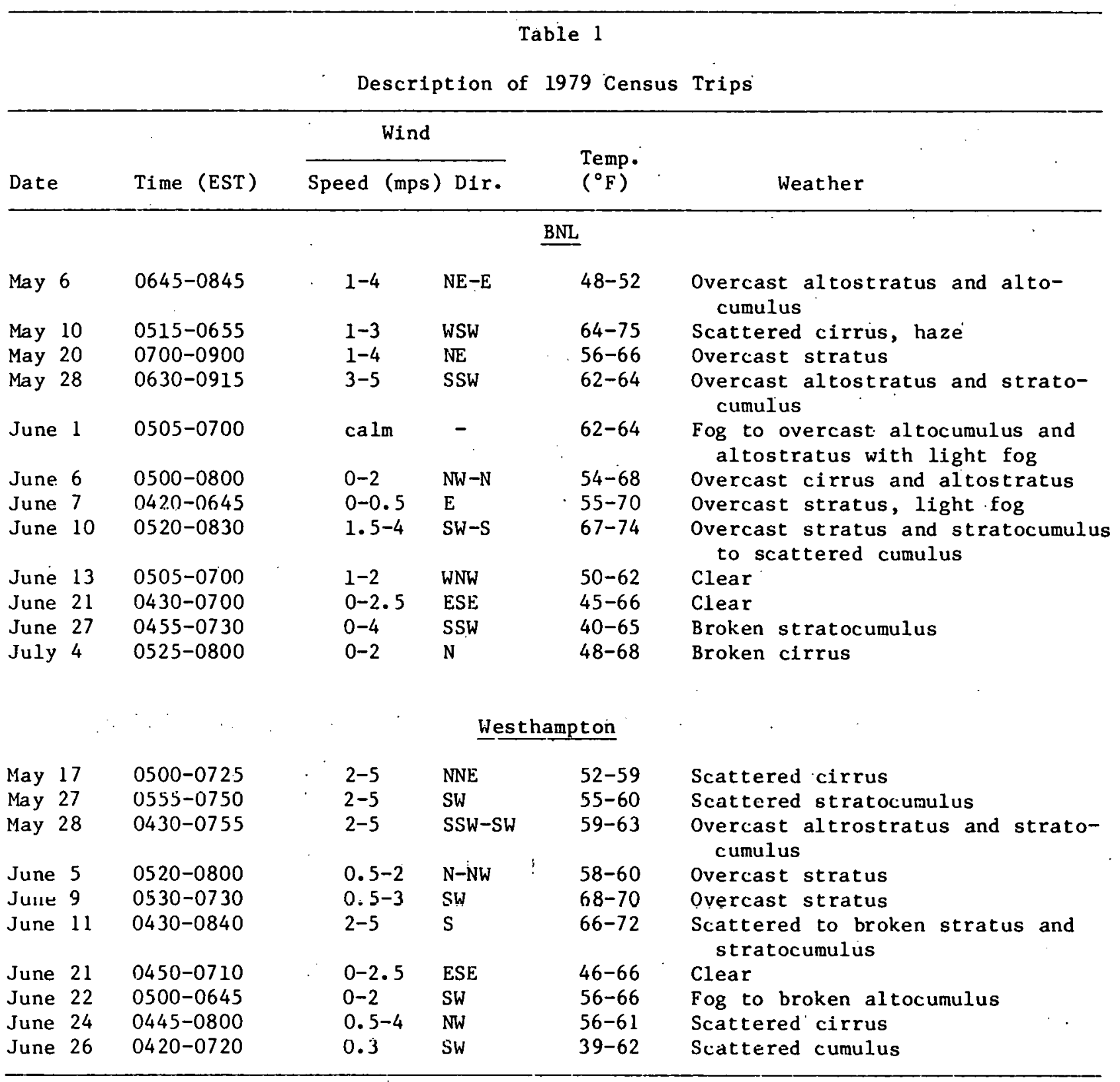


Table 2

Species Composition and Density of Territorial Males on BNL Plot in 1979

\begin{tabular}{lccc}
\hline Species & Territorial males & No./ $\mathrm{km}^{2}$ & No./100 acres \\
\hline Rufous-sided Towhee & 14 & 151 & 61 \\
Ovenbird & 7.5 & 73 & 33 \\
Brown Thrasher & 5 & 54 & 22 \\
Crested Flycatcher & 4 & 43 & 17 \\
Blue Jay & 4 & 43 & 17 \\
Black-capped Chickadee & 4 & 43 & 17 \\
Northern (Baltimore) Oriole & 3 & 32 & 13 \\
Hermit Thrush & 2 & 22 & 9 \\
Pine Warbler & 1.5 & 16 & 7 \\
Scarlet Tanager & + & - & - \\
\hline
\end{tabular}

Table 3

Species Composition and Density of Territorial Males on Westhampton Plot in 1979

\begin{tabular}{|c|c|c|c|c|c|}
\hline Specicn & Territo & rial & uales & $\mathrm{Nu} \cdot / \mathrm{km}^{2}$. & No./100 acrés \\
\hline Rufous-sided Towhee & $\vdots$ & 13: & : & 134 & 55 \\
\hline Prairie Warbler & & 12 & & 124 & 50 \\
\hline Ficld Sparrow & & 4 & & 41 . & 17 \\
\hline Brown Thrasher & & 3.5 & & 36 & 15 \\
\hline Common Yellowthroat & . & 2.5 & & 26 & 11 \\
\hline Marsh Hawk & & + & : & - & - \\
\hline Brown-headed Cowbird & & + & & - & - \\
\hline
\end{tabular}


Table 4

Number of Territorial Males on BNL P1ot, 1977-1979

\begin{tabular}{lccc}
\hline Species & 1977 & 1978 & 1979 \\
\hline Rufous-sided Towhee & 16.5 & 12.5 & 14 \\
Ovenbird & 8 & 7 & 7.5 \\
Crested Flycatcher & 3 & 3.5 & 4 \\
Northern (Baltimore) Oriole & 3 & 3.5 & 3 \\
Blue Jay & 5 & 3 & 4 \\
Black-capped Chickadee & 1 & 3 & 4 \\
Brown Thrasher & 1 & 1.5 & 5 \\
Hermit Thrush & 1 & 1.5 & 2 \\
Scarlet Tanager & 1.5 & 1.5 & + \\
Tufted Titmouse & 1 & 1 & $\mathrm{v}$ \\
Black and White Warbler & 3 & 1 & - \\
Pine Warbler & 1 & 1 & 1.5 \\
Common Flicker & 1 & + & $\mathrm{v}$ \\
Downy Woodpecker & 1 & + & $\mathrm{v}$ \\
Whip-poor-will & 2 & + & - \\
Wood Thrush & 2 & $\mathrm{v}$ & - \\
Common Yellowthroat & 1.5 & $\mathrm{v}$ & - \\
White-breasted Nuthatch & 1 & - & - \\
& & & \\
No. Species & 18 & 15 & 10 \\
No. Territorial Males & 53.5 & 40.0 & 45.0 \\
\hline & & &
\end{tabular}


Table 5

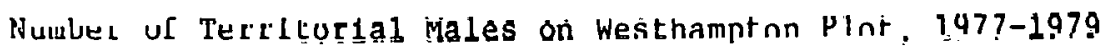

\begin{tabular}{lccc}
\hline Species & 1977 & 1978 & 1979 \\
\hline Prairie Warbler & 10 & 14.5 & 12 \\
Rufous-sided Towhee & 15 & 11.5 & 13 \\
Field Sparrow & 3.5 & 6 & 4 \\
Brown Thrasher & 2 & 2 & 3.5 \\
Common Yellowthroat & 3 & + & 2.5 \\
Mockingbird & $\mathrm{v}$ & + & $\mathrm{v}$ \\
Marsh Hawk & $\mathrm{v}$ & $\mathrm{v}$ & + \\
Brown-headed Cowbird & $\mathrm{v}$ & - & + \\
& & & 7 \\
No. Species & 5 & 6 & 35.0 \\
No. Territorial Males & 33.5 & 34.0 & \\
\hline
\end{tabular}




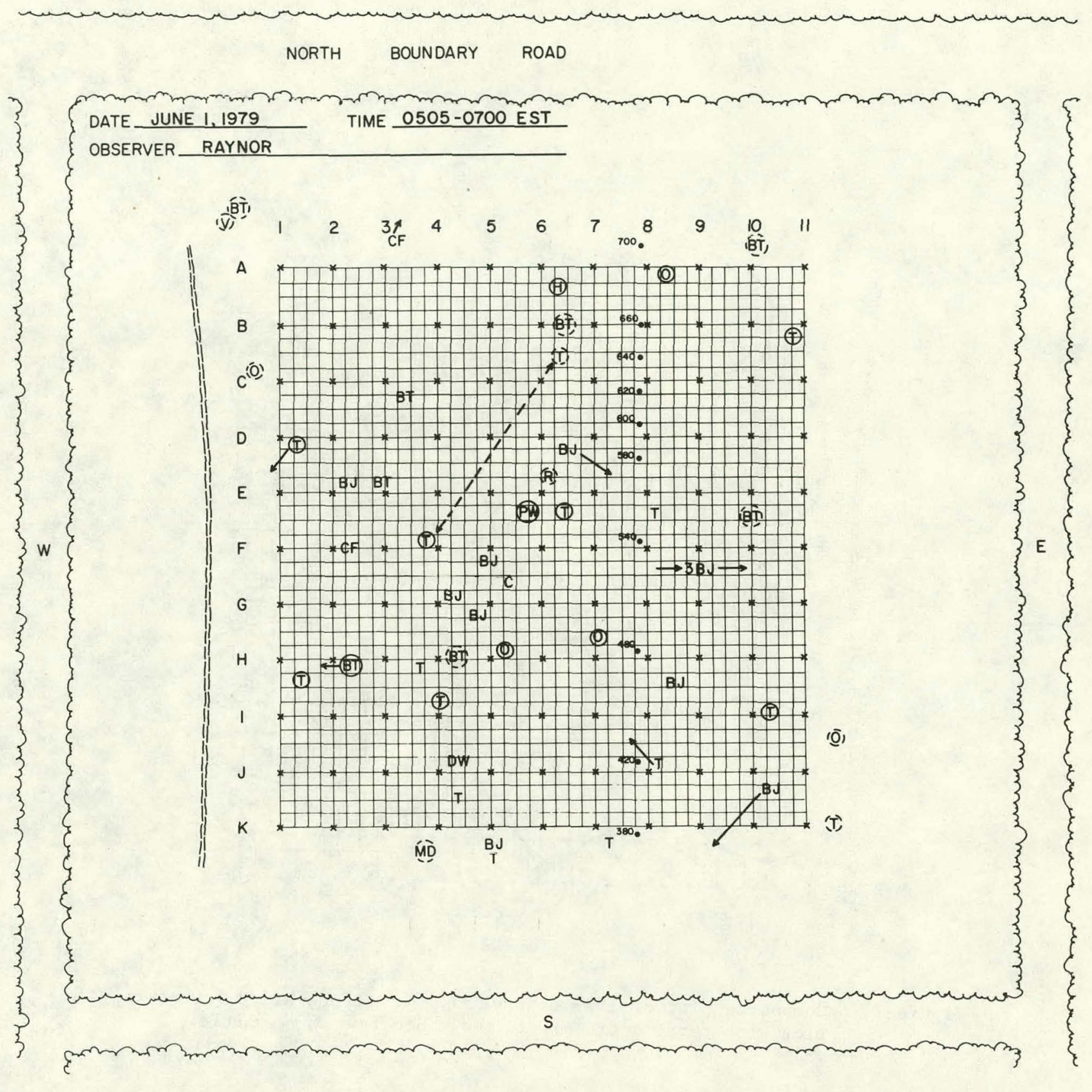

Figure 1 Map of BNL plot with observations from the June 1,1979 census visit. Letter symbuls are as follows: BJ - Blue Jay; BT - Brown Thrasher; C - Black-capped Chickadee; CF - Crested Flycatcher; DW - Downy Woodpecker; H - Hermit Thrush; MD - Mourning Dove; o - Ovenbird; PW - Pine Warbler; R - Kobin; T - Rufous-gided Towhee; V - Red-eyed Vireo. See text for meaning of other symbols. 


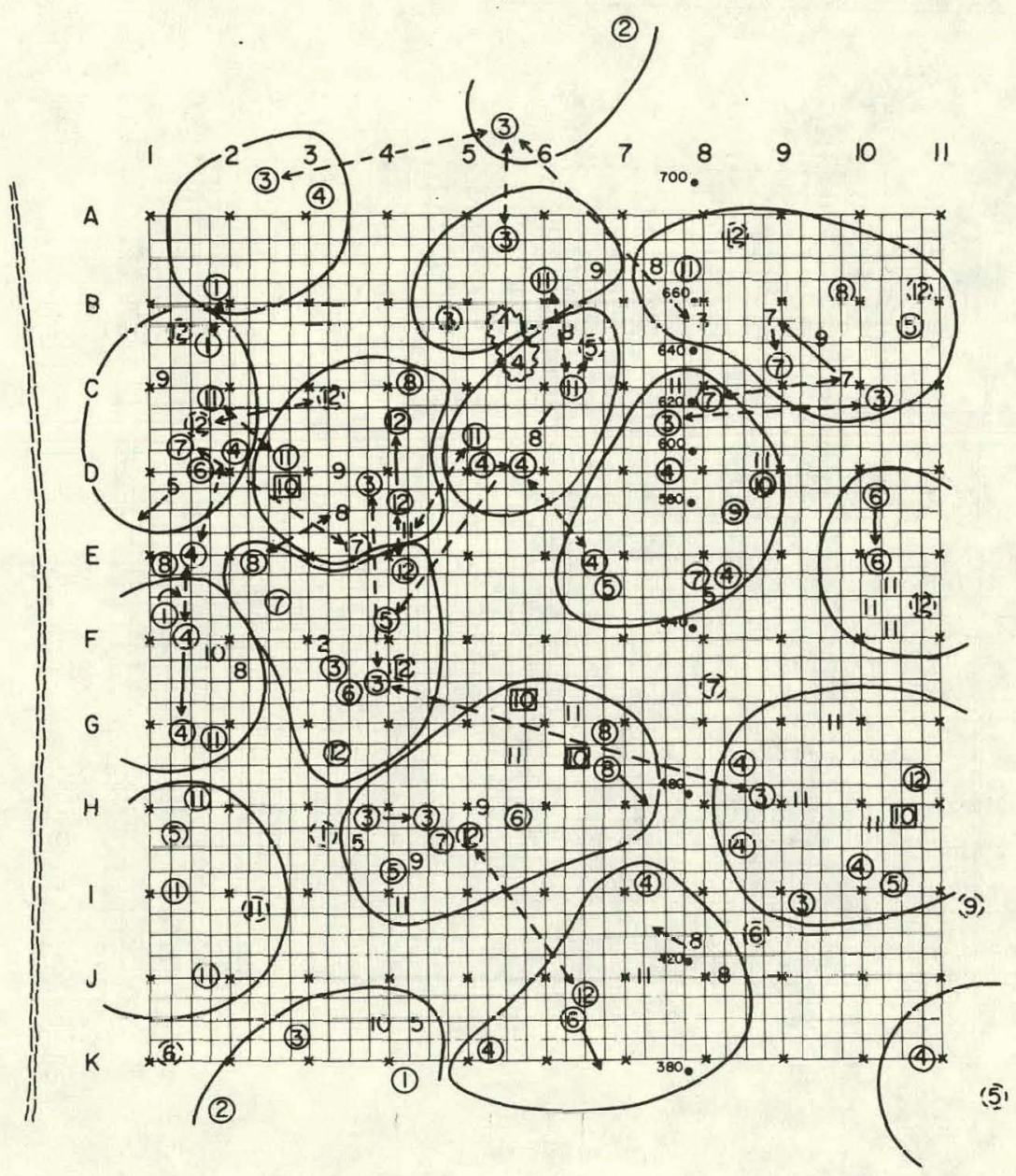

Figure 2 Composite plot of 1979 observations of Rufous-sided Towhee on BNL plot with territorial boundaries. Sec text for symbols. 


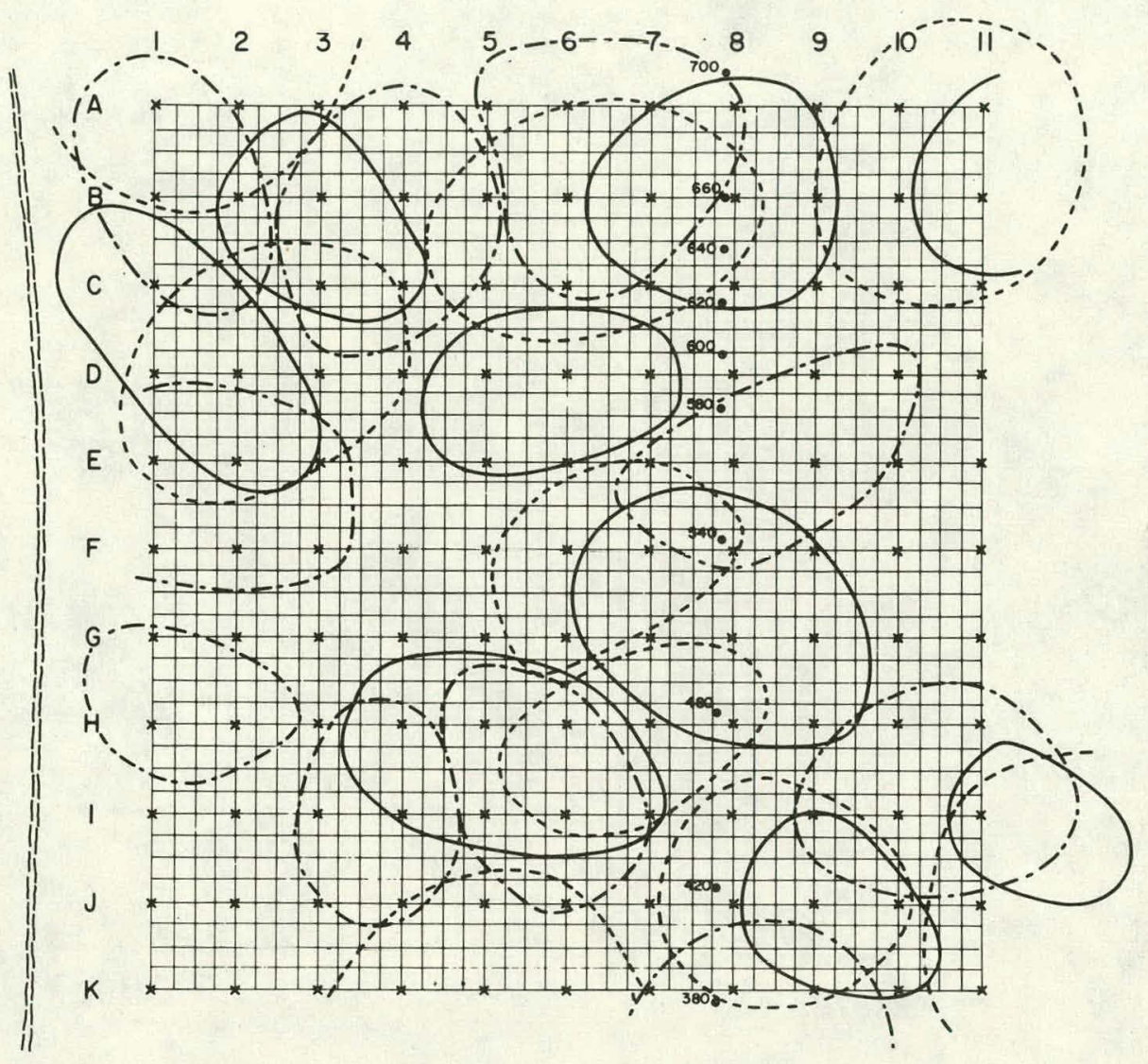

Figure 3 Ovenbird territories on BNL plot in 1977 (dot-dashed line), 1978 (dashed line), and 1979 (solid line). 